\title{
Glimpses of forest research, survey and extension activities in Nepal
}

\author{
A. Khadka ${ }^{\text {* }}$, B. P. Dhakal ${ }^{1}$, M. Paudel ${ }^{1}$, D. K. Pradhan ${ }^{1}$ and M. Kafle ${ }^{1}$
}

$\mathrm{M}$ anagement of forest has been an important aspect not only to meet the growing needs of the ever-increasing population but also to address the climate-related issues such as climate change, global warming, and biodiversity. Furthermore, forest is an important habitat for most of the wildlife on the earth. Like elsewhere, it is the most important asset that provides the basic needs and one of the major sources of Nepal's income (MFSC, 2013). Despite huge importance of forests, global forests are in crisis; nearly half of all global forests are under threats of deforestation and forest degradation forming a major risk to climate, biodiversity, water, people, and forest-based businesses (WWF, 2019).

To manage the existing forests scientifically, to establish new forests and to rehabilitate the degraded ones, inputs from forest research are imperative (Hamito, 2001). Properly addressing such emerging issues been a challenge worldwide. Several national, regional and international research organizations are committed to research excellence and interdisciplinary cooperation for discovering the science-based solutions and options for influencing policy processes.

In Nepal, number of organizations such as the Forest Research and Training Center (FRTC), Regional Community Forest Training Centre (RECOFTC), Asia Network for Sustainable Agriculture and Bioresources (ANSAB), Institute of Forestry (IOF) and International Centre for Integrated Mountain Development (ICIMOD) are involved in carrying out studies on forest research, survey and extension activities. However, FRTC is the only government body that has been mandated for carrying out forestry-related researches, surveys and trainings. Besides, it is a national correspondent and main organization for data generation to facilitate several international reporting including the Global Forest Resource Assessment (UN-FAO) and Monitoring, Reporting and Verification (MRV) of Reducing Emissions from Deforestation and Forest Degradation (REDD)+ Program.

\section{History of the FRTC}

In 1963, the then Forest Resources Survey Project (FRSP) was set up under the Department of Forests (DoF) to conduct forest resources survey. In 1976, it was upgraded as the Forest Survey and Research Office (FSRO), and the separate Research Faculty was created in Forestry Service. Later on, in 1988, the Survey component of this Office was merged with the then Ministry of Forests and Soil Conservation (MoFSC, now the Ministry of Forests and Environment- MoFE) as "Forest Survey and Statistics Division" while the Research component was amalgamated with the Department of Plant Resources as "Forest and Plant Research Division". Again in 1993, both the Research and Survey components were integrated as "Forest Research and Survey Centre (FORESC)", a semi-autonomous body directly under the then Ministry of Forests and Soil Conservation. Later on, in 1999, it was upgraded as the Department of Forest Research and Survey (DFRS). In 2018, this Department and the Central Forestry Training and Extension Centre (CFTEC), both under the Ministry of Forests and Environment were merged as the "Forest Research and Training Centre" (FRTC, 2019).

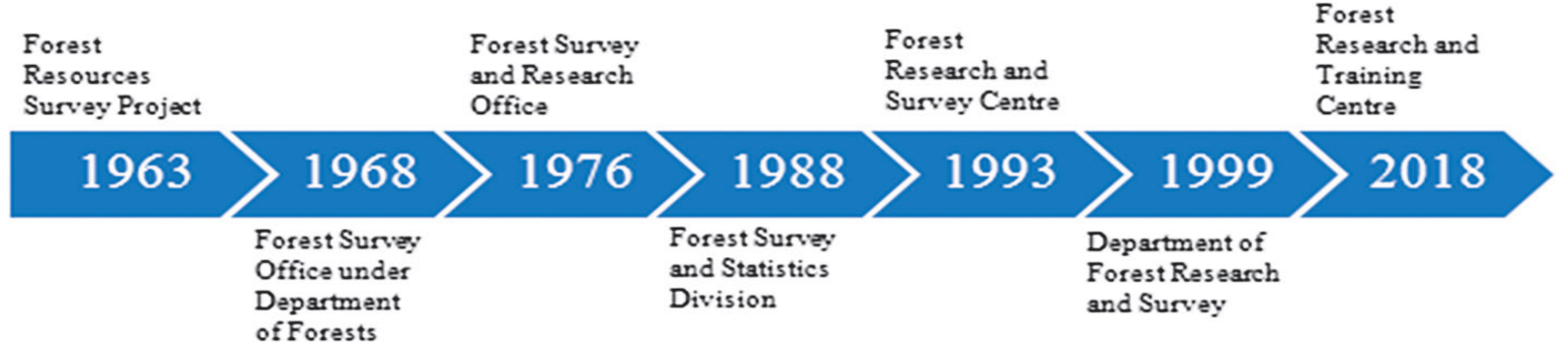

Figure 1 : History of the Forest Research and Training Centre.

1 Forest Research and Training Centre (FRTC), Kathmandu, Nepal. *E-mail : anandakhadka@gmail. com 


\section{Mandates of FRTC}

The FRTC has been mandated to carry out the following activities under the broad five themes, namely, i) Forest research; ii) Forest survey and mapping; iii) Soil laboratory; iv) Central Forest Library (CFL); and v) Training and Extension. Under these five themes, the Centre carries out the following activities on an annual basis :

- Researches on natural forests, plantations, nursery techniques and growth, silviculture, forest management, forest conversion, etc. ;

- Research on economically important tree species and non-timber forest products along with bamboo and rattans;

- Research on forest products utilization, biomass and volume Table ;

- Socio-economic researches on forestrelated themes, for instance, contribution of forestry sector in the national economy of Nepal;

- Agroforestry researches including feasibility studies and model diagnostics;

- National-level forest inventory (forest resources assessment);
- Mapping and updating of the forest cover, forest change detection, forest types, etc. at national-level;

- Digitization and archives of the available Aerial Photographs;

- Policy research;

- Testing of important soil properties (including N, P, K and SOC) in the Soil Laboratory;

- Management of the CFL to facilitate the researchers, students and other individuals interested in forestry-related subject matters with all the available study materials (books, journals, dissertations, newsletters and so on); and

- Provision of different forestry-related trainings to forestry professionals.

Key achievements of FRTC in forest research, survey and training sub-sectors

Plenty of research, survey and extension activities have been conducted by this organization so far. Some of the key achievements are listed in Table 1 below :

Table 1 : Key achievements made by FRTC in forest research, survey and training sectors

\begin{tabular}{|c|l|c|c|}
\hline S. N. & \multicolumn{1}{|c|}{ Program } & Year & Funding \\
\hline 1. & $\begin{array}{l}\text { In-service training for forest officers on "Forests for } \\
\text { development and administration" }\end{array}$ & Annually & GoN $^{\mathrm{i}}$ \\
\hline 2. & $\begin{array}{l}\text { Developing a methodology to assess the forestry } \\
\text { sector's contribution to national economy }\end{array}$ & 2019 & GoN \\
\hline 3. & $\begin{array}{l}\text { National-level forest and land cover analysis using } \\
\text { Google Earth Imageries }\end{array}$ & 2019 & $\begin{array}{c}\text { USAID }^{\mathrm{ii} / \text { WWF }} \\
\text { Nepal/ Hariyo Ban }\end{array}$ \\
\hline 4. & $\begin{array}{l}\text { Overview of different agroforestry models prevalent } \\
\text { in different ecological zones of Nepal }\end{array}$ & 2019 & GoN \\
\hline 5. & $\begin{array}{l}\text { Re-measurement of the permanent sample plots } \\
\text { (PSPs) }\end{array}$ & $2016-2019$ & GoN/ World Bank \\
\hline 6. & $\begin{array}{l}\text { Assessment of forest quality, growth and regeneration } \\
\text { in the scientifically managed forest of Kapilvastu } \\
\text { district }\end{array}$ & 2017 & GoN \\
\hline 7. & $\begin{array}{l}\text { Selection of appropriate species to rehabilitate } \\
\text { degraded lands in Churia and Mid-hills }\end{array}$ & 2017 & GoN \\
\hline 8. & $\begin{array}{l}\text { Volume Table s of Shorea robusta, Terminalia alata } \\
\text { and Anogeissus latifolia for Western Terai of Nepal }\end{array}$ & 2017 & GoN \\
\hline 9. & $\begin{array}{l}\text { Accessing dependency of the local people on Churia } \\
\text { forest resources }\end{array}$ & 2017 & GoN \\
\hline 10. & Forest Research Strategy & 2017 & GoN \\
\hline
\end{tabular}




\begin{tabular}{|c|c|c|c|}
\hline S. N. & Program & Year & Funding \\
\hline 11. & $\begin{array}{l}\text { Mapping deforestation and forest degradation of the } \\
\text { Churia region of eastern Nepal }\end{array}$ & 2015 & GoN \\
\hline 12. & $\begin{array}{l}\text { Identification of land reclamation area and potential } \\
\text { plantation area on Bagmati river-basin in the Terai } \\
\text { region of Nepal }\end{array}$ & 2015 & GoN \\
\hline 13. & $\begin{array}{l}\text { Assessment of regeneration potential, quality and } \\
\text { growth of } S \text {. robusta forest in the Terai region of } \\
\text { Nepal }\end{array}$ & 2015 & GoN \\
\hline 14. & $\begin{array}{l}\text { Livelihood improvement of disadvantaged } \\
\text { communities through bamboo cultivation and } \\
\text { capacity enhancement }\end{array}$ & $2013-2015$ & $\begin{array}{l}\text { USAID/WWF Nepal/ } \\
\text { Hariyo Ban }\end{array}$ \\
\hline 15. & $\begin{array}{l}\text { नर्सरीमा रोग कीराहरुको रोकथाम र न्यूनीकरण (Preventative and } \\
\text { control methods of disease and pest in Nursery) }\end{array}$ & 2012 & GoN \\
\hline 16. & $\begin{array}{l}\text { Review of traditional deigns and technologies of } \\
\text { bamboo and rattan in Nepal }\end{array}$ & 2011 & $\begin{array}{l}\text { GoN/ MDBRPPiv } \\
\text { Project }\end{array}$ \\
\hline 17. & National-level Forest Resource Assessment (FRA) & $2010-2014$ & $\begin{array}{l}\text { GoN/ Government of } \\
\text { Finland }\end{array}$ \\
\hline 18. & $\begin{array}{l}\text { Review of developed western markets for bamboo } \\
\text { and rattan commodities of Nepal }\end{array}$ & 2010 & $\begin{array}{l}\text { GoN/ MDBRPP } \\
\text { Project } \\
\end{array}$ \\
\hline 19. & $\begin{array}{l}\text { Assessment of Trees Outside Forest : Nawalparasi } \\
\text { and Dhanusha Districts }\end{array}$ & 2008 & GoN \\
\hline 20. & Management option for degraded Sal Forest in Terai & 2009 & GoN \\
\hline 21. & $\begin{array}{l}\text { रिठाको बीउ उपचार विधिबारे जानकारी (Information on seed } \\
\text { treatment technique of Sapindus mukorossi) }\end{array}$ & 2009 & GoN \\
\hline 22. & $\begin{array}{l}\text { नीमको प्रोभिनेन्स ट्रायल सम्बन्धी अध्ययन (Study on provenance } \\
\text { trail of Azadirachta indica) }\end{array}$ & 2008 & GoN \\
\hline 23. & $\begin{array}{l}\text { कलमी उत्पादन क्षेत्र स्थापना एवं व्यवस्थापन र कलमी तयारी बारे जानकारी } \\
\text { (Information on establishment and management of } \\
\text { coppice production area and coppice preparation) }\end{array}$ & 2008 & GoN \\
\hline 24. & $\begin{array}{l}\text { Establishment of research plots of Moso Bamboo } \\
\text { (Phyllostachys pubescens) in Kavre district (for } \\
\text { scientific study) }\end{array}$ & 2007 & GoN \\
\hline 25. & $\begin{array}{l}\text { नेपालमा पाटे सल्ला र खोटे सल्ला वृक्षारोपण वन पत्ल्याउने सम्बन्धी } \\
\text { मार्गदर्शन (Thinning guidelines for Pinus patula and } P \text {. } \\
\text { roxbughii plantation forests) }\end{array}$ & 2007 & GON \\
\hline 26. & $\begin{array}{l}\text { Studies on the growing stock of different species } \\
\text { of bamboo and rattan in Nepal, their utilization and } \\
\text { market potential, and plantation technique of Moso } \\
\text { Bamboo (P. pubescens) }\end{array}$ & $2005-2011$ & $\begin{array}{l}\text { DFRS/ MDBRPP } \\
\text { Project }\end{array}$ \\
\hline 27. & $\begin{array}{l}\text { तराई तथा भित्री मधेस को लागी बहुपयोगी क्यासियास्यामिया (Multipurpose } \\
\text { Cassia siamea for Terai and inner Terai) }\end{array}$ & 2005 & GON \\
\hline 28. & Participatory research in community forest in Nepal & 2004 & GoN \\
\hline 29. & $\begin{array}{l}\text { Impact of forest management on biodiversity in } \\
\text { community forests }\end{array}$ & 2004 & GoN \\
\hline 30. & $\begin{array}{l}\text { सालको प्राकृतिक पुनरुत्पादन प्रविधि (Natural regeneration } \\
\text { technique of S. robusta) }\end{array}$ & 2001 & GoN \\
\hline 31. & Wide area tropical forest resources survey of Nepal & 1999-2000 & $\mathrm{HMGN}^{\mathrm{v}} / \mathrm{JAFTA}^{\mathrm{vi}}$ \\
\hline
\end{tabular}




\begin{tabular}{|c|c|c|c|}
\hline S. $\mathbf{N}$. & Program & Year & Funding \\
\hline 32. & $\begin{array}{l}\text { Investigation on causal agents responsible for dieback } \\
\text { of D. sissoo in Terai belts of Nepal }\end{array}$ & 1999 & GoN \\
\hline 33. & $\begin{array}{l}\text { Deforestation in the Terai districts }(1978 / 79- \\
\text { 1990/91) }\end{array}$ & 1994 & HMGN \\
\hline 34. & $\begin{array}{l}\text { Volume equations and biomass predictions of forest } \\
\text { trees of Nepal }\end{array}$ & 1990 & HMGN \\
\hline 35. & National-level Forest Inventory (NFI) & $1987-1998$ & $\begin{array}{l}\text { GoN/ Government of } \\
\text { Finland }\end{array}$ \\
\hline 36. & Plantation trials in central and mid-western regions & $1983-1988$ & HMGN/ CFDPvii \\
\hline 37. & Plantation trials in Mid-hills of western region & $1982-1985$ & HMGN/ RCUP ${ }^{\text {viii }}$ \\
\hline 38. & Plantation trials in different parts of the country & $1981-1986$ & HMGN/ TCFPix \\
\hline 39. & Plantation trials of different tree species & $1980-1998$ & HMGN \\
\hline 40. & Plantation trials in the Inner Terai and Mid-hills & $1980-1985$ & HMGN/ SRP ${ }^{x}$ \\
\hline 41. & $\begin{array}{l}\text { Research on nursery and plantation techniques of } \\
\text { different tree and fodder species, management options } \\
\text { for different types of forest, agro-forestry techniques, } \\
\text { tree improvement, growth performance of different } \\
\text { species of bamboo, forest soil, forest pathology, forest } \\
\text { entomology, etc. }\end{array}$ & 1979-1996 & $\begin{array}{l}\text { HMGN/ FRP }{ }^{x i} \text { (Phase } \\
\text { I) }\end{array}$ \\
\hline 42. & $\begin{array}{l}\text { Plantation trials of different tree species (selection of } \\
\text { suiTable fast growing species and species elimination } \\
\text { trials) }\end{array}$ & $1964-1979$ & HMGN \\
\hline 43. & NFI & $1963-1967$ & HMGN/ USAID \\
\hline \multicolumn{4}{|c|}{$\begin{array}{l}\text { More information and publications are available at FRTC online library, url : shorturl. at/orJ02 and } \\
\text { website : www. frtc. gov. np }\end{array}$} \\
\hline
\end{tabular}

Note : ${ }^{\mathrm{i}}$ Government of Nepal; ii United States Agency for International Development; ${ }^{\text {iii }}$ World Wildlife Fund; iv Market Development for Bamboo and Rattan Products with Potential; His Majesty's Government of Nepal; vi Japan Foresters' Technical Association; vii Community Forestry Development Project; viii Resource Conservation and Utilization Project; ix Terai Community Forestry Project; $\mathrm{x}$ Silvicultural Research Project; ${ }^{\text {xi }}$ Forestry Research Project.

\section{FRTC in federal system}

The constitution of Nepal has provisioned three levels of government- i) federal-level government, ii) provincial-level government, and iii) local-level government. The FRTC has been restructured and established at the federal and provincial levels accordingly. The FRTC at the center (i.e. Kathmandu) remains under the Federal Government. Besides, seven province-level FRTCs have been established under the province governments- one each in all the seven provinces.

\section{Key issues and needs}

Since its establishment, the FRTC has done its level best to identify the knowledge gaps (with respect to the resources available) and disseminate information to the concerned stakeholders. However, regarding technology and skill development, it has not been able to convey the services as required. Furthermore, an increasing thirst of innovations at local- and practitioner-levels has not been accomplished so far. The following issues and future needs have been identified to strengthen the research, survey and extension of forestry sector :

- $\quad$ Poor networking and collaboration with national and international institutions;

- Lack of coherence in dissemination of research results, extension and knowledge management;

- Inability to resolve the growth performance of the presently preferred species such as Agarwood (Aquilaria spp. ), Bodhichitta 
(Ziziphus budhensis), Paulownia spp., Red sandalwood (Pterocarpus santalinus), etc. at practitioner-level;

- Weak implementation of research findings;

- Need for training manuals and Training of Trainers (ToTs);

- Database management;

- Lack of advanced technology and equipment;

- Low priority on research;

- Monitoring and Evaluation;

- No institutional incentives and motivation; and

- Need for a detailed guideline to address the following requirements :

- Integration of forestry researches being conducted by several institutions e. g. the FRTC, Department of Forests and Soil Conservation (DoFSC, earlier DoF), REDD-Implementation Centre, etc. ;

- Consistency in methods, data, imageries, resources and accuracy; and

- A rigid definition of burning terminologies, e. g. forest degradation.

\section{Advancement}

Nevertheless, the FRTC is pursuing its best to achieve the targets and overcome the related issues, accordingly. The Ministry of Forests and Environment had requisitioned the FRTC (Central) to conduct the technical auditing of the community-managed forests under scientific forest management. Henceforth, the FRTC got approval for a program on "Technical auditing of scientific forest management". Besides, a program on "Internship of Students from Forestry Science" has been approved to enhance the technical capability of forestry manpower. Furthermore, to obtain reliable and more precise results from the Soil Laboratory, accreditation procedure has been initiated.
Since the generation of scientific results and information has not been fully accomplished due to the lack of coordination and collaboration with different research institutions, the FRTC has started to build up collaboration with different research/survey organizations to carry out various forest-related research/survey activities. Recently, a program on "Bamboo resource inventory" has been approved to assess the bamboo resources all over the country and to further collaborate with the International Network for Bamboo and Rattan (INBAR). Besides, the FRTC and the ICIMOD are working together to develop a National Land Cover Monitoring System (NLCMS) to analyze and map out the national land cover status on an annual basis. Likewise, the FRTC has been technically supported by the SilvaCarbon and the University of Maryland (UMD) to strengthen its capacity on image-based forest cover mapping and monitoring.

\section{References}

FRTC. 2019. Forest Research and Training Center, Kathmandu, Nepal. https://www.frtc.gov.np.

Hamito, D. 2001. Research methods in forestry principles and practices with particular reference to Ethiopia.

MFSC. 2013. Country report on the state of forest genetic resources, Nepal. Government of Nepal, Ministry of Forests and Soil Conservation, Kathmandu, Nepal.

WWF. 2019. Collaborating to conserve forests : HP and WWF Project goes beyond responsible sourcing toward a healthier planet. Web story on WWF Gifts. https : // www. blogarama. com/travel-blogs/264636 (published on $23^{\text {rd }}$ September, 2019). 